Copyright (C) The Author(s), 2020. Published by Cambridge University Press on behalf of The American Society of International Law.

doi:10.1017/amp.2020.1

\title{
CORRIGENDUM
}

\section{AMP Volume 113 Cover and Front Matter-CORRIGENDUM}

In the original published front matter, the Chairs of the Committee of the Annual Meeting and the Co-Editors of the 2019 ASIL Proceedings were incorrect. The correct Chairs and Co-Editors are listed below. This has since been updated in the original published table of contents online.

Rebecca Ingber

Neha Jain

Rahim Moloo

\section{REFERENCE}

1. AMP Volume 113 Cover and Front Matter. Proceedings of the ASIL Annual Meeting, 113, iii-viii. doi: https://doi.org/10.1017/amp.2019.213. 